\title{
Antiproliferative activity of essential oils derived from plants belonging to the Magnoliophyta division
}

\author{
ILARIA LAMPRONTI ${ }^{1}$, ANTOINE M. SAAB ${ }^{3}$ and ROBERTO GAMBARI ${ }^{1,2}$ \\ ${ }^{1}$ ER-GenTech, Department of Biochemistry and Molecular Biology, Section of Molecular Biology, ${ }^{2}$ Biotechnology Center, \\ University of Ferrara, Ferrara, Italy; ${ }^{3}$ Chemistry Department, Faculty of Sciences II, Lebanese University, Beirut, Lebanon
}

Received December 23, 2005; Accepted February 21, 2006

\begin{abstract}
The essential oils obtained from different officinal plants of Lebanon, belonging to the Magnoliophyta division, have been tested for their antiproliferative activity on human erythroleukemic K562 cells. Satureja montana showed the most interesting biological activity in inhibiting the cell growth and inducing erythroid differentiation of K562 cells. The essential oil of Satureja montana was therefore analyzed using a GC/MS (gas chromatography/mass spectrometry) system in order to identify the major constituents and compare them with analysis performed on Satureja hortensis. We demonstrated that the essential oil composition varied with the species, the major constituent of Satureja hortensis being carvacrol $(50.61 \%)$ and that of Satureja montana being $\alpha$-terpineol $(12.66 \%)$. In order to identify molecules possibly responsible for the biological activity, commercially available derivatives have been assayed on the K562 cell line. Satureja montana essential oil displayed different natural derivatives characterized by higher activity than those present in Satureja hortensis. The common active principles are $\alpha$-pinene, $\gamma$-terpinene, 4 -terpineol, $\alpha$-terpineol, $\tau$-cadinene, $\tau$-cadinol and caryophyllene. Both caryophyllene and $\alpha$-terpineol showed important antiproliferative effects on K562 cells.
\end{abstract}

\section{Introduction}

The interest in medicinal plants and their biologically active derivatives has increased in recent years, in relation to the possible development of novel potential drugs for several pathologies of relevant social impact $(1,2)$. In fact, it is well known that medicinal plants are described and used in prenatal

Correspondence to: Professor Roberto Gambari, Department of Biochemistry and Molecular Biology, Section of Molecular Biology, University of Ferrara, Via L. Borsari 46, 44100 Ferrara, Italy E-mail: gam@unife.it

Key words: Satureja montana, antiproliferative activity, anticancer agents, medicinal plants, Magnoliophyta division care, in obstetrics, in gynaecology, in respiratory disorders, in skin disorders, in cardiac diseases, in nervous and muscular disorders and in mental health (3-7).

With respect to potential anti-tumor activity, possible applications of medicines for cancer prevention have been recently described (8-16). Aegle marmelos and Emblica officinalis, both medicinal plants derived from Bangladesh and studied by our research group, demonstrated remarkable antiproliferative activity on different human tumor cell lines (17-20).

In order to further identify plants exhibiting antiproliferative activity, we analyzed a variety of officinal plants from Lebanon and belonging to the Magnoliophyta division, including Satureja hortensis, Satureja montana, Salvia officinalis, Lavandula officinalis, Thymus vulgaris, Calamintha origanifolia, Foeniculum vulgare and Mentha arvensis. From the Mediterranean area, several medicinal plants from Lebabon have been described (21-23). For instance, Barbour et al (23) tested the in vitro antimicrobial efficacy of extracts derived from different parts of 27 indigenous wild plant species that have been commonly used in Lebanese folk medicine. However, despite these interesting findings, few biological data are available for most medicinal plants from Lebanon.

All obtained essentials oils and related available pure compounds were analyzed for their antiproliferative activity on human K562 cells. Also, their ability to induce erythroid differentiation was determined.

\section{Materials and methods}

Essential oils from Satureja hortensis and Satureja montana. The fresh leaves of S. montana and S. hortensis were collected on Sannine Mountain in Lebanon, in July 2003 when fully flowering, at a 1800-m altitude. The collected species were authenticated according to conventional methods. Then, $200 \mathrm{~g}$ of fresh leaves and flowers of each species were submitted to hydro-distillation for $2 \mathrm{~h}$ with 21 of solvent. The essential oils were finally dried over anhydrous sodium sulfate to remove traces of moisture and give a yield of $0.85 \%$. The obtained essential oils were stored at $4^{\circ} \mathrm{C}$.

Essential oils from Salvia officinalis, Lavandula officinalis, Thymus vulgaris, Calamintha origanifolia, Foeniculum vulgare and Mentha arvensis. The fresh leaves (200-300 g) of Salvia officinalis, Lavandula officinalis, Thymus vulgaris, Calamintha 
origanifolia and Mentha arvensis and the leaves and seeds (200 g) of Foeniculum vulgare were collected in Lebanon in March 2003. All of the Lebanese plants were harvested in a flowering vegetative state, except Salvia officinalis, which was collected before the flowering season in the Ain-saadeh region $(600 \mathrm{~m})$. Thymus vulgaris and Mentha arvensis came from the Baskinta region (1400 m), Lavandula officinalis and Foeniculum vulgare were collected in the Kfarakaab and Ain-alkabou regions, respectively (1200 m); and Calamintha origanifolia was harvested at Bakish Mount, Lebanon $(1800 \mathrm{~m})$. All the collected species were authenticated according to conventional methods. Samples of each species were submitted to hydro-distillation for $2 \mathrm{~h}$ with 21 of solvent. The essential oils were dried over anhydrous sodium sulfate to remove traces of moisture.

Cell lines, culture conditions and assays of in vitro antiproliferative activity. Human erythroleukemia K562 cells (18) were cultured in a humidified atmosphere at $5 \% \mathrm{CO}_{2}$, in RPMI-1640 (Flow laboratories, Irvine, UK) supplemented with $10 \%$ fetal bovine serum (FBS; CELBIO, Milano, Italy), 100 units $/ \mathrm{ml}$ penicillin and $100 \mathrm{mg} / \mathrm{ml}$ streptomycin (Aldrich, St. Louis, MO, USA). The in vitro antiproliferative activity of essential oils and pure commercially available derivatives from $S$. montana and $S$. hortensis was assayed as follows. Cell number/ml was determined by using a model ZBI Coulter Counter (Coulter Electronics, Hialeah, FL). Cells were seeded at an initial concentration of $3 \times 10^{4}$ cells $/ \mathrm{ml}$ and the cell number/ml was determined after 2, 3, 4 and 5 days of cellculture. The $\mathrm{IC}_{50}$ was usually determined after 4 days, when untreated cells are in the log phase of cell growth.

Assays of in vitro induction of erythroid differentiation. Erythroid differentiation of essential oils from S. montana and $S$. hortensis and their pure derivatives was determined by counting benzidine positive cells after suspending the cells in a solution containing $0.2 \%$ benzidine in $0.5 \mathrm{M}$ glacial acetic acid, $10 \% \mathrm{H}_{2} \mathrm{O}_{2}$, as elsewhere described (24-26). Induction of differentiation was compared with that obtained using well established inducers of differentiation of K562 cells, such as cytosine arabisonide (27), mithramycin (28), angelicin (29), hydroxyurea (30) and butyric acids (31).

Gas chromatography/mass spectrometry (GC/MS) analysis of essential oils from Satureja montana and Satureja hortensis. A Fisons (Thermo Finnigan, San Jose, CA) model GC 8000 gas chromatograph interfaced to a Fisons model MD 800 quadrupole mass spectrometer was used for all measurements. The fused-silica gas chromatographic capillary column was a MEGA SE 54 (methyl phenyl polysiloxanes), $25 \mathrm{~m} \mathrm{x} 0.25 \mathrm{~mm}$ I.D. and $0.25 \mu \mathrm{m}$ film thickness (32). The head pressure of the carrier gas (helium, $99.99 \%$ purity) was $50 \mathrm{kPa}$ (7.2 p.s.i.). One $\mu \mathrm{l}$ of sample dissolved into appropriate solvents was injected into the gas chromatograph. The injector and detector temperatures for the gas chromatograph were $250^{\circ} \mathrm{C}$ and $300^{\circ} \mathrm{C}$, respectively. The column oven temperature was increased linearly from $40^{\circ} \mathrm{C}$ (held for $4 \mathrm{~min}$ ) to $200^{\circ} \mathrm{C}$ (held for $10 \mathrm{~min}$ ) at $10^{\circ} \mathrm{C} / \mathrm{min}$. The mass spectrometer operated at source and interface temperatures of $250^{\circ} \mathrm{C}$. The ionization mode was Electron Impact (E.I.) $(70 \mathrm{eV})$. The 'solvent

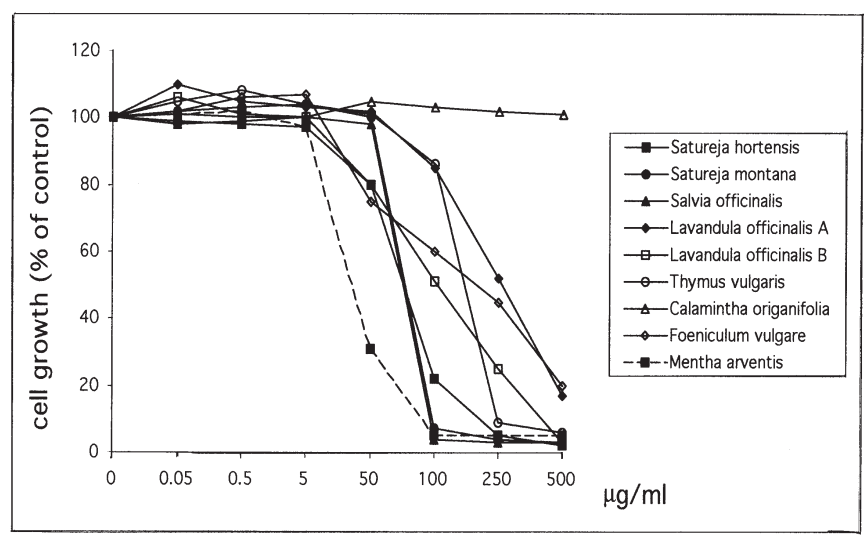

Figure 1. Effects of increasing concentrations of essential oils from Lebanon on K562 cell growth. L. officinalis A, plant cultivated in silice land; $L$. officinalis $B$, plant cultivated in argile land. Cells were cultured for 4 days and the cell number/ml was determined and compared to the value obtained using control untreated K562 cells.

Table I. Effects of essential oils from Lebanon on K562 cell growth $\left(\mathrm{IC}_{50}\right)$ and differentiation (\% of benzidine-positive cells after 5 days of culture at the indicated concentrations).

\begin{tabular}{lcc}
\hline Essential oil & $\begin{array}{c}\mathrm{IC}_{50} \\
(\mu \mathrm{g} / \mathrm{ml})\end{array}$ & $\begin{array}{c}\% \text { Differentiation } \\
(\mu \mathrm{g} / \mathrm{ml})\end{array}$ \\
\hline Satureja hortensis & $85.4 \pm 2.4$ & $16(0.5-5)$ \\
Satureja montana & $56.15 \pm 6.15$ & $30(0.05-50)$ \\
Salvia officinalis & $217.7 \pm 0.5$ & $23(0.5-50)$ \\
$\begin{array}{l}\text { Lavandula officinalis } \\
\text { (silice land) }\end{array}$ & $256.1 \pm 0.3$ & $18(0.05-50)$ \\
$\begin{array}{l}\text { Lavandula officinalis } \\
\text { (argile land) }\end{array}$ & $111.6 \pm 24.6$ & $11(0.05-5)$ \\
Thymus vulgaris & $136.6 \pm 25$ & $25(0.05-0.5)$ \\
Calamintha origanifolia & $>500$ & $34(5-250)$ \\
Foeniculum vulgare & $190.8 \pm 0.5$ & $32(5-50)$ \\
Mentha arvensis & $40.6 \pm 3.5$ & $13(0.5)$ \\
\hline
\end{tabular}

delay', the time gap of a given analysis in which the mass spectrometer is turned off, was $3 \mathrm{~min}$. The GC/MS system was operated in 'full scan' mode. The software utilized was Excalibur (Fisons) with NIST library to recognize all the derivatives found in plant extracts.

\section{Results}

Effects of essential oils on in vitro proliferation of human leukemic K562 cells. Fig. 1 shows the effects of increasing amounts of essential oils derived from Satureja hortensis, Satureja montana, Salvia officinalis, Lavandula officinalis, Thymus vulgaris, Calamintha origanifolia, Foeniculum vulgare and Mentha arvensis on cell proliferation of K562 cells. We analyzed two different essential oils derived from 


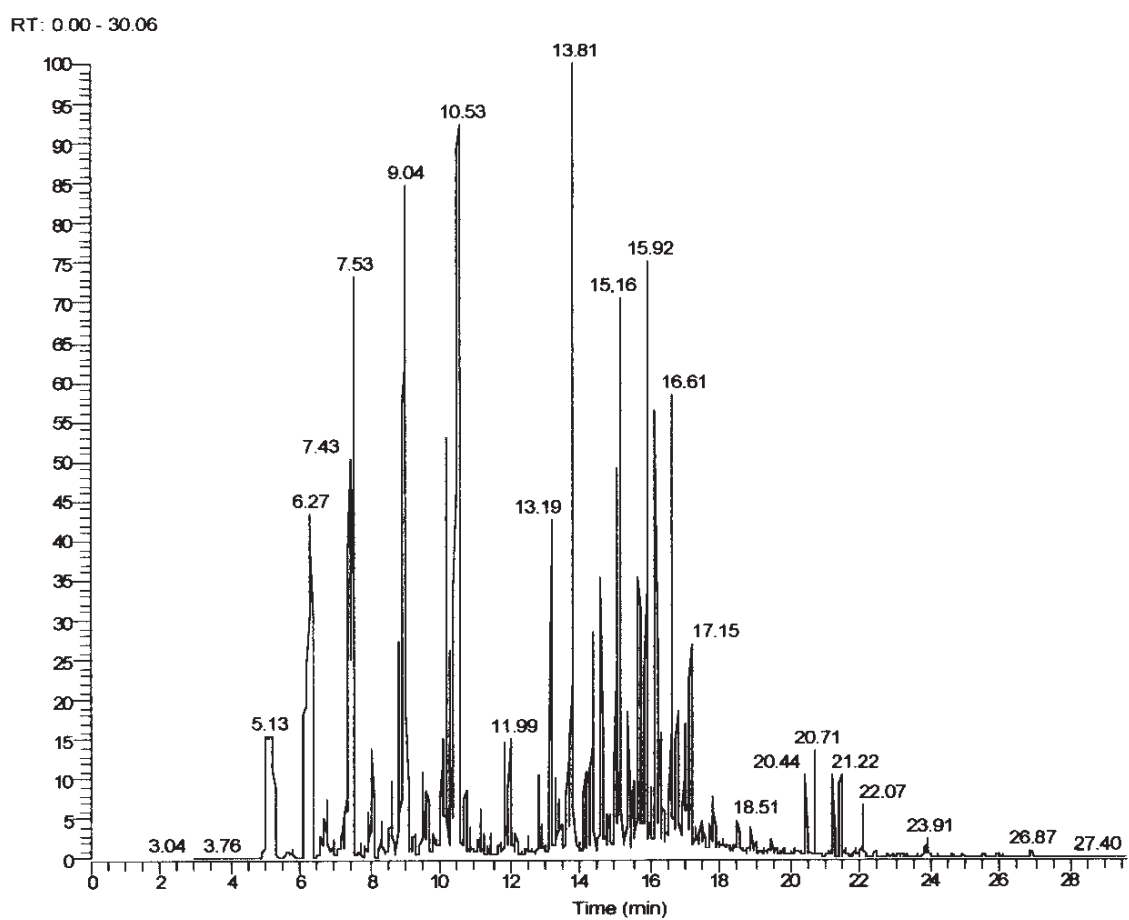

A

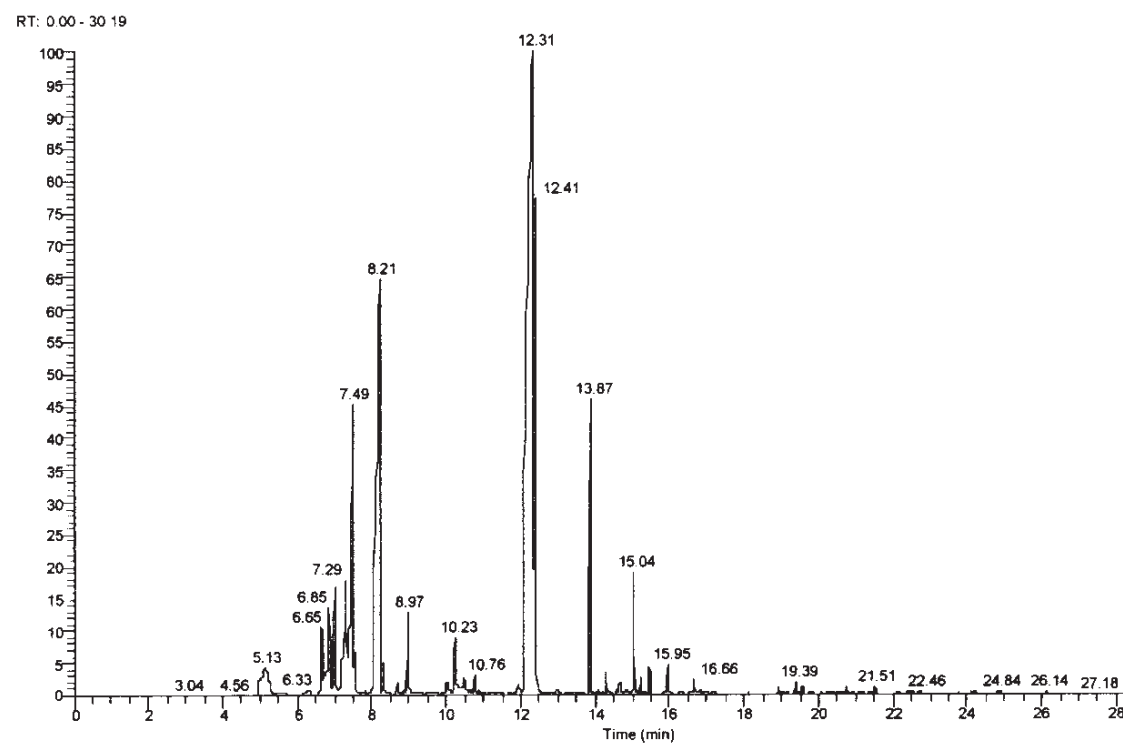

B

Figure 2. Chromatograms obtained with GC/MS of Satureja montana (A) and Satureja hortensis (B) essential oils.

L. officinalis cultivated in silice and argile land. K562 cells were seeded at an initial concentration of $30000 \mathrm{cells} / \mathrm{ml}$ and then cultured for 7 days in the absence or presence of 0.05 $500 \mu \mathrm{g} / \mathrm{ml}$ of all of the hydro-distillate essential oils. The obtained data show that the $\mathrm{IC}_{50}$ of $S$. hortensis, $S$. montana and $M$. arvensis essential oils were $85.4 \pm 2.4,56.15 \pm 6.15$ and $40.6 \pm 3.5 \mu \mathrm{g} / \mathrm{ml}$, respectively. The essential oil extracted from C. origanifolia was completely unable to inhibit K562 cell growth at the used concentrations $\left(\mathrm{IC}_{50}>500 \mu \mathrm{g} / \mathrm{ml}\right)$, and the remaining extracts demonstrated an intermediate activity.
The data resulting from three different experiments are summarized in Table I, indicating that the essential oils derived from $S$. montana and $M$. arvensis showed the most interesting biological activity in inhibiting the cell growth of the K562 cell line.

Effects on K562 erythroid differentiation. Since it is well known that many antiproliferative agents are able to exert their anti-tumor effects by the activation of terminal programs of differentiation of targeted tumor cells, we tested the ability 
of all essential oils to induce the erythroid differentiation of K562 cells (33). K562 erythroid differentiation was analyzed as reported elsewhere by the benzidine-staining procedure (24-26). C. origanifolia, F. vulgare and S. montana induced differentiation $(30-34 \%)$ at concentrations lower than that causing 50\% inhibition of K562 cell growth. Also, Thymus vulgaris and Salvia officinalis induced intermediate levels of differentiation $(25 \%)$, whereas the percentage of differentiation decreased (13-18\%) when Lavandula officinalis, Mentha arvensis and Satureja hortensis were employed (Table I).

In our opinion, Satureja montana differs from the other essential oils because its high antiproliferative effect is associated to the interesting ability to induce erythroid differentiation of K562 cells. Accordingly, Satureja montana extracts were further analyzed to identify putative bioactive compounds.

Gas chromatography/mass spectrometry analysis of Satureja montana and Satureja hortensis. In order to identify putative active compounds present within Satureja montana essential oil, we employed a gas chromatography/mass spectrometry (GC/MS) system. We decided to analyze and compare Satureja montana and Satureja hortensis. S. montana and $S$. hortensis essential oils were dissolved in acetonitrile $(2 \%$ $\mathrm{V} / \mathrm{V})$ and $1 \mu \mathrm{l}$ of each solution was injected into the gas chromatograph using an appropriate microsyringe, chromatographed using a fused-silica capillary column and analyzed with a quadrupole mass spectrometric detector. The resulting chromatograms are represented in Fig. 2 (A, Satureja montana; B, Satureja hortensis) and indicate that, in both assayed essential oils, seven derivatives are present, corresponding to $\alpha$-pinene, $\gamma$-terpinen, 4-terpineol, $\alpha$-terpineol, caryophyllene, $\tau$-cadinene and $\tau$-cadinol. The other identified molecules differ between the analyzed oils. All the compounds corresponding to the major peaks identified are shown in Tables II and III (Satureja montana and Satureja hortensis, respectively). The commercially available derivatives ( $\alpha$-pinene, $\beta$-pinene, 1 octen-3-ol, 3-octanol, $\gamma$-terpinen, B-linalool, borneol, 4terpineol, carvacrol, caryophyllene, $\alpha$-caryophyllene, caryophyllene oxide, eucalyptol, copaene and \pm trans-nerolidol) were tested for their antiproliferative and differentiating activities on K562 cells.

Biological activities of pure compounds identified within essential oils from Satureja montana and Satureja hortensis. The commercially available compounds present in Satureja montana and Satureja hortensis were analyzed for their antiproliferative activity and also for their possible effect on K562 differentiation, in order to identify putative active derivatives. We tested 15 pure compounds, identifying three derivatives present within the plant extracts very active in inhibiting K562 cell growth, including $\alpha$-terpineol $\left(\mathrm{IC}_{50}=\right.$ $75.0 \mu \mathrm{M})$, caryophyllene $\left(\mathrm{IC}_{50}=98.0 \mu \mathrm{M}\right)$ and $\alpha$-caryophyllene $\left(\mathrm{IC}_{50}=98.7 \mu \mathrm{M}\right)$. Caryophyllene and $\alpha$-terpineol are present in both essential oils, but at a different concentration; caryophyllene represents $6.66 \%$ of relative composition in Satureja montana (Table II) and 3.85\% in Satureja hortensis (Table III), whereas $\alpha$-terpineol represents $12.66 \%$ in $S$. montana and $0.38 \%$ in $S$. hortensis. In Table IV, the $\mathrm{IC}_{50}$ is reported for all compounds tested with respect to the ability to inhibit K562
Table II. Composition of Satureja montana essential oil.

\begin{tabular}{|c|c|c|}
\hline $\begin{array}{l}\text { R.t. } \\
(\min )\end{array}$ & Components & $\begin{array}{l}\text { Composition } \\
(\%)\end{array}$ \\
\hline 5.13 & $\alpha$-pinene & 4.35 \\
\hline 6.27 & 4(10)-thujene & 7.00 \\
\hline 7.43 & p-mentha-1,8-dien-6-ol & 1.00 \\
\hline 7.53 & eucalyptol (1,8-cineole) & 8.87 \\
\hline 8.08 & $\gamma$-terpinen & 1.03 \\
\hline 9.04 & ß-linalool & 11.41 \\
\hline 9.48 & (E)-3(10)-caren-4-ol & 1.15 \\
\hline 9.65 & $(\mathrm{~S})$-cis-verbenol & 0.18 \\
\hline 10.19 & 4-terpineol & 3.98 \\
\hline 10.53 & $\alpha$-terpineol (p-menth-1-en-8-ol) & 12.66 \\
\hline 10.72 & 2-pinen-4-one & 0.35 \\
\hline 11.85 & p-allyl-anisole & 0.13 \\
\hline 11.99 & nerol acetate & 1.58 \\
\hline 13.19 & copaene & 2.77 \\
\hline 13.81 & caryophyllene & 6.66 \\
\hline 14.61 & germacrene D & 1.70 \\
\hline 15.01 & $\tau$-cadinene & 0.44 \\
\hline 15.16 & cadina-1(10),4-diene & 6.05 \\
\hline 15.35 & $4,5,9,10$-dehydro-isolongifolene & 0.87 \\
\hline 15.68 & \pm trans-nerolidol & 2.57 \\
\hline 15.92 & caryophyllene oxide & 4.70 \\
\hline 16.16 & ledol & 3.00 \\
\hline 16.61 & $\tau$-cadinol & 2.73 \\
\hline 16.76 & $\alpha$-cadinol & 0.94 \\
\hline 17.15 & $\begin{array}{l}\text { 4-(2-acetyl-5,5'-dimethylcyclopent- } \\
\text { 2-enylidene)butan-2-one }\end{array}$ & 1.20 \\
\hline 20.71 & labda-8(20),13(16),14-triene & 0.57 \\
\hline 21.19 & 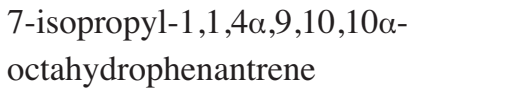 & 0.48 \\
\hline 22.07 & $\begin{array}{l}\text { p-(2,2,4-trimethyl-4- } \\
\text { chromanyl)phenol }\end{array}$ & 0.35 \\
\hline
\end{tabular}

Total: 88.72

cell growth. From the data shown in Table IV, it is clearly evident that some compounds exhibit no antiproliferative activity, e.g. eucaliptol, 1-octen-3-ol, 3-octanol and m-cymene $\left(\mathrm{IC}_{50}>400 \mu \mathrm{M}\right)$. Three molecules found in both essential oils ( $\alpha$-pinene, $\alpha$-terpineol and caryophyllene) exhibit high antiproliferative activity, even if at different concentrations $\left(\mathrm{IC}_{50}=\right.$ $117.3 \mu \mathrm{M}, 75.0 \mu \mathrm{M}$ and $98.7 \mu \mathrm{M}$, respectively). Interestingly, all of these active compounds are more concentrated in Satureja montana, which is more active as crude extract than Satureja hortensis $\left(\mathrm{IC}_{50}=56.15 \pm 6.15 \mu \mathrm{g} / \mathrm{ml}\right.$ and $85.4 \pm 2.4 \mu \mathrm{g} /$ $\mathrm{ml}$, respectively).

Since Satureja montana induce erythroid differentiation of K562 cells ( $30 \%$ of induction with concentrations ranging between 0.05 and $50 \mu \mathrm{g} / \mathrm{ml}$ ), we also analyzed the effects of the identified bioactive components utilizing the benzidinestaining procedure. No compound showed any detectable 
Table III. Composition of Satureja hortensis essential oil.

\begin{tabular}{|c|c|c|}
\hline $\begin{array}{l}\text { R.t. } \\
(\min )\end{array}$ & Components & $\begin{array}{l}\text { Composition } \\
(\%)\end{array}$ \\
\hline 5.13 & $\alpha$-pinene & 2.19 \\
\hline 6.65 & 1-octen-3-ol (amyl vinyl carbinol) & 1.21 \\
\hline 6.85 & ß-pinene & 2.34 \\
\hline 6.99 & 3-octanol & 2.03 \\
\hline 7.49 & m-cymene & 9.07 \\
\hline 8.21 & $\gamma$-terpinene & 15.26 \\
\hline 8.97 & ß-linalool & 1.29 \\
\hline 10.01 & borneol & 0.28 \\
\hline 10.23 & 4-terpineol & 1.19 \\
\hline 10.76 & $\alpha$-terpineol (p-menth-1-en-8-ol) & 0.38 \\
\hline 11.92 & trans-geraniol & 0.02 \\
\hline 12.31 & carvacrol & 50.61 \\
\hline 12.97 & acethyl thymol & 0.08 \\
\hline 13.87 & caryophyllene & 3.85 \\
\hline 14.29 & $\alpha$-caryophyllene & 0.33 \\
\hline 15.01 & $\tau$-cadinene & 0.11 \\
\hline 15.04 & $\begin{array}{l}\text { 1-methyl-4-(methyl-1-methylene- } \\
\text { 4-hexenyl)-cyclohexene }\end{array}$ & 1.49 \\
\hline 15.95 & caryophyllene oxide & 0.43 \\
\hline 16.66 & $\tau$-cadinol & 0.24 \\
\hline
\end{tabular}

Total: 92.4

activity in inducing erythroid differentiation of K562 cells (Table IV).

The obtained results suggest that the antiproliferative effects found in several active compounds of Satureja montana, including $\alpha$-pinene, $\gamma$-terpinen, $\beta$-linalool, terpineol, carvacrol, caryophyllene, caryophyllene oxide, copaene and \pm transnerolidol, are not associated to induction of differentiation.

The ability of $S$. montana extracts to induce erythroid differentiation could be ascribed to other unidentified or not commercially available pure compound(s) and/or to a combination of singularly inactive molecules.

\section{Discussion}

The first objective of our study was to compare the activity of essential oils derived from plants belonging to the Magnoliophyta division on the in vitro proliferation and erythroid differentiation of human leukemic K562 cells. The second objective was to analyze the most promising extracts by $\mathrm{GC} / \mathrm{MS}$ in order to characterize them with respect to composition. The third objective was to determine the biological activity of some identified pure compounds on K562 cells, in order to correlate the biological activity of the plant extracts with specific identified molecules.

To these aims, we determined the effects of essential oils from Satureja hortensis, Satureja montana, Salvia officinalis, Lavandula officinalis, Thymus vulgaris, Calamintha origanifolia, Foeniculum vulgare and Mentha arvensis on the
Table IV. Effects of pure compounds identified in Satureja montana and Satureja hortensis on $\mathrm{K} 562$ cell growth $\left(\mathrm{IC}_{50}\right)$ and differentiation ( $\%$ of benzidine-positive cells after 5 days of culture at the indicated concentrations).

\begin{tabular}{lcl}
\hline Compound & $\mathrm{IC}_{50}(\mu \mathrm{M})$ & $\begin{array}{c}\% \text { Differentiation } \\
(\mu \mathrm{M})\end{array}$ \\
\hline$\alpha$-pinene & $117.3 \pm 14.4$ & $5(10)$ \\
B-pinene & $157.4 \pm 21.6$ & $4(50)$ \\
eucalyptol & $>400$ & $3(10)$ \\
$\gamma$-terpinene & $329.9 \pm 0.5$ & $3(200)$ \\
linalool & $150.0 \pm 3.5$ & $5(100)$ \\
$\alpha$-terpineol & $75.0 \pm 1.5$ & $4(100)$ \\
copaene & $136.5 \pm 3.2$ & $4(50)$ \\
trans-nerolidol & $132.9 \pm 4.6$ & $3(50)$ \\
caryophyllene & $98.0 \pm 0.7$ & $4(50)$ \\
$\alpha$-caryophyllene & $98.7 \pm 1.2$ & $4(5-50)$ \\
caryophyllene oxide & $136.4 \pm 2.5$ & $7(10)$ \\
1-octen-3-ol & $>400$ & $4(400)$ \\
3-octanol & $>400$ & $3(50-200)$ \\
m-cymene & $>400$ & $4(200-400)$ \\
carvacrol & $112.5 \pm 12.2$ & $7(400)$ \\
\hline
\end{tabular}

in vitro proliferation and erythroid differentiation of human leukemic K562 cells. We found that the essential oil derived from Satureja montana showed the most interesting biological activity in inhibiting the cell growth and in inducing also erythroid differentiation of the K562 cell line. This result is of some importance, since data on the biological activity of $S$. montana extracts are scarce. Among the available data, it was reported that the essential oils of S. montana have a broad spectrum of activity against multidrug-resistant pathogens. The highest activity of the savory oil was observed against Escherichia coli, methicillin-resistant Staphylococcus aureus and yeasts (Candida albicans) (34). Furthermore, S. montana essential oil is active in inhibiting germination, releasing phytotoxic monoterpenes that hinder the development of herbaceous species (35). Finally, S. montana showed also potent anti-HIV-1 activity (36). S. hortensis has been used as tea or additive in commercial spice mixtures for food and also as a folk remedy to treat various ailments such as cramps, muscle pains, nausea, indigestion, diarrhea, and infectious diseases. In the literature, it is demonstrated that this medicinal plant shows antispasmodic, antidiarrheal, antioxidant, sedative, antifungal and antimicrobial properties (37). The in vitro antimicrobial and antioxidant activities of essential oils from $S$. hortensis have been previously reported, together with the chemical composition obtained by GC/MS, starting from airdried and ground aerial parts collected in Turkey (37).

Concerning the characterization of bioactive compounds present in the studied plant extracts, we used a GC/MS system and we were able to identify several molecules, some of which were found to be able to inhibit K562 cell growth. Interestingly, $\alpha$-pinene, $\alpha$-terpineol and caryophyllene exhibited high anti-proliferative activity, even at different concentrations 
$\left(\mathrm{IC}_{50}=117.3 \mu \mathrm{M}, 75.0 \mu \mathrm{M}\right.$ and $98.0 \mu \mathrm{M}$, respectively) and were found to be more concentrated in Satureja montana, which is more active as a crude extract than Satureja hortensis (compare Tables II and III). Therefore, we found very good correlation between the studies on the unfractionated plant extracts and the analysis of biological effects of isolated compounds on K562 cell growth.

This correlation was not found when erythroid differentiation was determined in K562 cells treated with pure compounds. None of the analyzed compounds showed detectable activity. Therefore, we suggest that the molecule(s) responsible for erythroid induction are not among the compounds analyzed or, alternatively, that erythroid differentiation is induced by a combination of the identified compounds. Further experiments are required to discriminate between these two possibilities.

In any case, our study suggests that $\alpha$-pinene, $\beta$-pinene, B-linalool, terpineol, copaene, trans-nerolidol, caryophyllene, caryophyllene oxide and carvacrol, which are structurally related molecules, deserve further evaluation as molecules inhibiting the proliferation of tumor cells in vitro and in vivo.

\section{Acknowledgements}

This work is funded by CIB (Consorzio Interuniversitario di Biotecnologie, Italy), AVLT (Associazione Veneta per la Lotta alla Talassemia, Italy), SPINNER and PRRIITT (EU, Obiettivo 2), and CARIPARO (Fondazione della Cassa di Risparmio di Padova e Rovigo).

\section{References}

1. Hedberg I: Botanical methods in ethnopharmacology and the need for conservation of medicinal plants. J Ethnopharmacol 38: 121-128, 1993.

2. Heinrich M and Gibbons S: Ethnopharmacology in drug discovery: an analysis of its role and potential contribution. J Pharm Pharmacol 53: 425-432, 2001.

3. Ahmad I, Mehmood Z and Mohammad F: Screening of some Indian medicinal plants for their antimicrobial properties. J Ethnopharmacol 62: 183-193, 1998.

4. Datta BK, Rahman I and Das TK: Antifungal activity of Indian plant extracts. Mycoses 41: 535-536, 1998.

5. Ankli A, Heinrich M, Bork P, Wolfram L, Bauerfeind P, Brun R, Schmid C, Weiss C, Bruggisser R, Gertsch J, Wasescha M and Sticher O: Yucatec Mayan medicinal plants: evaluation based on indigenous uses. J Ethnopharmacol 79: 43-52, 2002.

6. Abo KA, Adeyemi AA and Adeite DA: Ethnobotanical survey of plants used in the treatment of infertility and sexually transmitted diseases in southwest Nigeria. Afr J Med Med Sci 29: 325-327, 2000.

7. Pinn G: Herbs used in obstetrics and gynaecology. Aust Fam Physician 30: 351-356, 2001.

8. Chang FR, Hsieh TJ, Huang TL, Chen CY, Kuo RY, Chang YC, Chiu HF and Wu YC: Cytotoxic constituents of the stem bark of Neolitsea acuminatissima. J Nat Prod 65: 255-258, 2002.

9. Cragg GM and Newman DJ: Discovery and development of antineoplastic agents from natural sources. Cancer Invest 17: 153-163, 1999.

10. Katsube N, Iwashita K, Tsushida T, Yamaki K and Kobori M: Induction of apoptosis in cancer cells by Bilberry (Vaccinium myrtillus) and the anthocyanins. J Agric Food Chem 51: 68-75, 2003.

11. Mukherjee AK, Basu S, Sarkar N and Ghosh AC: Advances in cancer therapy with plant based natural products. Curr Med Chem 8: 1467-1486, 2001.

12. Richardson MA: Biopharmacologic and herbal therapies for cancer: research update from NCCAM. J Nutr 131: 3037-3040, 2001.
13. Tatman D and Mo H: Volatile isoprenoid constituents of fruits, vegetables and herbs cumulatively suppress the proliferation of murine B16 melanoma and human HL-60 leukemia cells. Cancer Lett 175: 129-139, 2002.

14. Wargovich MJ, Woods C, Hollis DM and Zander ME: Herbals, cancer prevention and health. J Nutr 131: 3034-3036, 2001.

15. Popov AM, Atopkina LN, Uvarova NI and Elyakov GB: The antimetastatic and immunomodulating activities of ginseng minor glycosides. Dokl Biochem Biophys 380: 309-312, 2001.

16. Ruffa MJ, Ferraro G, Wagner ML, Calcagno ML, Campos RH and Cavallaro L: Cytotoxic effect of Argentine medicinal plant extracts on human hepatocellular carcinoma cell line. J Ethnopharmacol 79: 335-339, 2001.

17. Jose JK, Kuttan G and Kuttan R: Antitumour activity of Emblica officinalis. J Ethnopharmacol 75: 65-69, 2001.

18. Lampronti I, Martello D, Bianchi N, Borgatti M, Lambertini E, Piva R, Jabbar S, Choudhuri MS, Khan MT and Gambari R: In vitro antiproliferative effects on human tumor cell lines of extracts from the Bangladeshi medicinal plant Aegle marmelos Correa. Phytomedicine 10: 300-308, 2003.

19. Khan MT, Lampronti I, Martello D, Bianchi N, Jabbar S, Choudhuri MS, Datta BK and Gambari R: Identification of pyrogallol as an antiproliferative compound present in extracts from the medicinal plant Emblica officinalis: effects on in vitro cell growth of human tumor cell lines. Int J Oncol 21: 187-192, 2002 .

20. Sharma N, Trikha P, Athar M and Raisuddin S: In vitro inhibition of carcinogen-induced mutagenicity by Cassia occidentalis and Emblica officinalis. Drug Chem Toxicol 23: 477-484, 2000.

21. Bruno M, Bondi ML, Rosselli S, Maggio A, Piozzi F and Arnold NA: Neoclerodane diterpenoids from Teucrium montbretii subsp. libanoticum and their absolute configuration. J Nat Prod 65: 142-146, 2002.

22. Lev E: Some evidence for the use of doctrine of signatures in the land of Israel and its environs during the Middle Ages. Harefuah 141: 651-655, 2002.

23. Barbour EK, Al-Sharif M, Sagherian VK, Habre AN, Talhouk RS and Talhouk SN: Screening of selected indigenous plants of Lebanon for antimicrobial activity. J Ethnopharmacol 93: 1-7, 2004.

24. Bianchi N, Chiarabelli C, Borgatti M, Mischiati C, Fibach E and Gambari R: Accumulation of gamma-globin mRNA and induction of erythroid differentiation after treatment of human leukaemic K562 cells with tallimustine. Br J Haematol 113: 951-961, 2001.

25. Bianchi N, Ongaro F, Chiarabelli C, Gualandi L, Mischiati C, Bergamini $P$ and Gambari R: Induction of erythroid differentiation of human K562 cells by cisplatin analogs. Biochem Pharmacol 60: 31-40, 2000.

26. Gambari R: The human erythroleukemia K562 cell culture system for identification of inducers of fetal hemoglobin. Minerva Biotecnologica 15: 123-128, 2003.

27. Cortesi R, Gui V, Osti F, Nastruzzi C and Gambari R: Human leukemic K562 cells treated with cytosine arabinoside: enhancement of erythroid differentiation by retinoic acid and retinol. Eur J Haematol 61: 295-301, 1998

28. Bianchi N, Osti F, Rutigliano C, Corradini FG, Borsetti E, Tomassetti M, Mischiati C, Feriotto G and Gambari R: The DNA-binding drugs mithramycin and chromomycin are powerful inducers of erythroid differentiation of human K562 cells. Br J Haematol 104: 258-265, 1999.

29. Lampronti I, Bianchi N, Borgatti M, Fibach E, Prus E and Gambari R: Accumulation of gamma-globin mRNA in human erythroid cells treated with angelicin. Eur J Haematol 71: 189-195, 2003.

30. Iyamu EW, Adunyah SE, Fasold H, Horiuchi K, Baliga S, Ohene-Frempong K. Turner EA and Asakura T: Combined use of non-myelosuppressive nitrosourea analogues with hydroxyurea in the induction of F-cell production in a human erythroleukemic cell line. Exp Hematol 31: 592-600, 2003.

31. Hoffman R, Murnane MJ, Benz EJ, Prohaska R, Floyd V, Dainiak N, Forget BG and Furthmayr H: Induction of erythropoietic colonies in a human chronic myelogenous leukemia cell line. Blood 54: 1182-1187, 1979.

32. Assimopoulou AN and Papageorgiou VP: GC-MS analysis of penta- and tetra-cyclic triterpenes from resins of Pistacia species. Part I. Pistacia lentiscus var. Chia. Biomed Chromatogr 19: 285-311, 2005. 
33. Gambari R and Fibach E: Induction of fetal hemoglobin by DNA-binding drugs. Minerva Biotecnologica 15: 145-151, 2003.

34. Skocibusic $\mathrm{M}$ and Bezic N: Phytochemical analysis and in vitro antimicrobial activity of two Satureja species essential oils. Phytother Res 18: 967-970, 2004.

35. Angelini LG, Carpanese G, Cioni PL, Morelli I, Macchia M and Flamini G: Essential oils from Mediterranean lamiaceae as weed germination inhibitors. J Agric Food Chem 51: 6158-6164, 2003.
36. Yamasaki K, Nakano M, Kawahata T, Mori H, Otake T, Ueba N, Oishi I, Inami R, Yamane M, Nakamura M, Murata $\mathrm{H}$ and Nakanishi T: Anti-HIV-1 activity of herbs in Labiatae. Biol Pharm Bull 21: 829-833, 1998.

37. Gulluce M, Sokmen M, Daferera D, Agar G, Ozkan H, Kartal N, Polissiou M, Sokmen A and Sahin F: In vitro antibacterial, antifungal, and antioxidant activities of the essential oil and methanol extracts of herbal parts and callus cultures of Satureja hortensis L. J Agric Food Chem 51: 3958-3965, 2003. 